p-ISSN : 2597-8977

e-ISSN : $2597-8985$

Sitti Rahma Yunus *)

Universitas Negeri Makassar

Muhammad Aqil Rusli Universitas Negeri Makassar

Nurhayani H. Muhiddin Universitas Negeri Makassar

Hasanuddin Universitas Negeri Makassar

*) Correspondence Author: sittirahmayunus@unm.ac.id

\section{ANALISIS HUBUNGAN ANTARA KETERAMPILAN PROSES SAINS, MOTIVASI, DAN HASIL BELAJAR IPA SEKOLAH CALON GURU IPA}

Abstrak: Tujuan penelitian ini untuk mengetahui: 1.) Hubungan antara keterampilan proses sains (KPS) dengan hasil belajar IPA sekolah calon guru IPA, 2.) Hubungan antara motivasi belajar dengan hasil belajar IPA sekolah calon guru IPA. Jenis penelitian yang digunakan adalah penelitian survey yang bersifat korelasional dengan populasi adalah seluruh mahasiswa S-1 Prodi Pendidikan IPA FMIPA UNM Makassar yang mengikuti kuliah Praktikum IPA Sekolah pada tahun akademik 2017/2018 sejumlah 53 orang. Instrumen penelitian terdiri dari 1) tes KPS, 2) tes hasil belajar, dan 3). Angket motivasi belajar. Keterampilan proses sains calon guru IPA pada kelas ICP dan reguler berada pada kategori tinggi. Skor rata-rata motivasi belajar baik pada kelas reguler maupun kelas ICP berada pada kategori tinggi. Rata-rata skor hasil belajar pada kelas ICP adalah 83 sedangkan pada kelas regular 71. Selanjutnya hasil analisis korelasi menunjukkan bahwa korelasi antara keterampilan proses dengan hasil belajar calon guru IPA pada kelas reguler berada pada kategori rendah dan pada kelas ICP berada pada kategori sedang atau cukup. Korelasi antara motivasi dengan hasil belajar calon guru IPA pada kelas Reguler maupun kelas ICP berada kategori rendah.

Kata Kunci: Keterampilan proses sains, Motivasi belajar, hasil belajar.

Abstract: The aims of this study are to find out the correlation of science process skills and learning motivation towards science learning outcomes of science pre-service teacher. This research is a survey study. The population is all undergraduate students of the Science Study Program of Mathematic and Natural Science Faculty of Universitas Negeri Makassar who attend the School Science Practicum course in the 2017/2018 academic year. The research instrument consisted of 1) science process skills tests, 2) learning outcomes tests, and 3). Questionnaire for learning motivation. The results indicate that the lowest score is in the indicator "write the operational definition of variables" with enough categories. The average score of learning motivation in both the regular and ICP classes is in the high category. The average score of learning outcomes in the ICP class is 83 while in the regular class 71. Furthermore, the results of the correlation analysis show that the correlation between process skills and learning outcomes of prospective science teachers in regular class is at low category and in ICP class is at moderate category. The correlation between motivation and learning outcomes of prospective science teachers in the Regular and ICP classes is at low category.

Keyword: Scientific process skill, Motivation, Learning outcomes. 


\section{PENDAHULUAN}

Proses perolehan informasi sains melalui penyelidikan diperlukan keterampilan. Salah satu keterampilan dalam penyelidikan IPA adalah keterampilan proses sains. (KPS). KPS melibatkan keterampilan intelektual, manual, dan sosial yang digunakan untuk membangun pemahaman terhadap suatu konsep atau pengetahuan dan meyakinkan atau menyempurnakan pemahaman yang sudah terbentuk. (Dimyati \& Moedjiono, 2002). Memiliki keterampilan proses sains yang baik menjadi keharusan bagi para mahasiswa calon guru IPA. Oleh karena merekalah yang akan mengajarkan IPA pada penerus bangsa.

Keterampilan proses sains adalah dasar untuk berpikir ilmiah dan melakukan penelitian. (Mutlu dan Temmis, 2013: Aydogdu, 2015). KPS didefinisikan sebagai identifikasi masalah, merumuskan hipotesis mengenai suatu masalah, membuat prediksi yang valid, mengidentifikasi dan mendefinisikan variabel, mendesain percobaan untuk menguji hipotesis, memperoleh dan menganalisis data serta mepresentasikan temuan yang mendukung data. (Tobin \& Capie, 1962; Bass, et al, 2005).

Pengetahuan dan keterampilan proses sains hendaknya berjalan beriringan. Peningkatan keterampilan proses sains seharusnya dibarengi dengan peningkatan hasil belajar. Hal ini sesuai dengan penelitian sebelumnya pada subjek yang berbeda. Beberapa peneliti sebelumnya pernah melakukan penelitian terkait yaitu hasil penelitian Tuti Respati (2013) menunjukkan terdapat hubungan yang positif dan berarti antara pemahaman keterampilan proses sains dengan hasil belajar biologi siswa kelas XI IPA SMA Negeri 1 Padang.

Untuk dapat memperoleh hasil yang baik dalam pengetahuan maupun keterampilan, mahasiswa calon guru IPA harusnya memiliki motivasi dalam belajar. Motivasi berkaitan dengan apa yang kita diinginkan (tujuan), mengapa kita menginginkannya (motif), dan bagaimana kita mencapai tujuan tersebut (proses).

Hakikat motivasi belajar adalah dorongan internal dan eksternal pada peserta didik peserta didik yang sedang belajar untuk mengadakan perubahan tingkah laku, pada umumnya dengan beberapa indicator atau unsure yang mendukung. Hal itu mempunyai peranan besar dalam keberhasilan seseorang dalam belajar

Berdasarkan latar belakang tersebut, maka peneliti melakukan survey hubungan antara keterampilan proses sains, motivasi dengan hasil belajar mahasiswa calon guru IPA. Secara detail yang ingin dilihat adalah hubungan antara keterampilan proses sains dengan hasil belajara dan hubungan antara motivasi belajar dengan hasil belajar.

\section{METODE}

Jenis penelitian yang digunakan adalah penelitian survey yang bersifat korelasional dengan populasi adalah seluruh mahasiswa S-1 Prodi Pendidikan IPA FMIPA UNM Makassar yang mengikuti kuliah Praktikum IPA Sekolah pada tahun akademik 2017/2018 sejumlah 53 orang. Variabel bebas penelitian ini yakni (1) Keterampilan Proses Sains dan (2) motivasi belajar, sedang variabel tak bebasnya yakni hasil belajar IPA Sekolah. Penelitian ini mencari hubungan antara keterampilan proses sains dengan hasil belajar dan motivasi beljar dengan hasil belajar.

Instrumen penelitian terdiri dari 1) tes keterampilan proses sains (KPS), 2) tes hasil belajar, dan 3). Angket motivasi belajar. Instrument keterampilan proses dan tes hasil belajar dikembangkan oleh peneliti dan melalui proses validasi isi sedangkan angket motivasi belajar diambil dari angket yang sudah ada yang sudah melewati proses validasi ahli.

Data yang diperoleh dianalisis secara statistif deskriptif dan inferensial. Hasil data tes KPS, hasil belajar, dan motivasi belajar dianalisis secara deskriptif untuk melihat nilai rata-rata dari masing-masing variabel selanjutnya digunakan statsitik inferensial untu melihat korelasi antar variabel tersebut. 


\section{HASIL DAN PEMBAHASAN}

1. Hasil

a. Data KPS

Data keterampilan proses sains calon guru IPA (kelas ICP dan reguler) sebagai berikut:

Tabel 1. Data Skor Keterampilan Proses Sains Calon Guru IPA

\begin{tabular}{cccc}
\hline No & Statistik Data & Kelas ICP & Kelas Reguler \\
\hline $\mathbf{1}$ & Jumlah Sampel & 23 & 30 \\
$\mathbf{2}$ & Skor Maksimum & 40 & 40 \\
$\mathbf{3}$ & Skor Minimum & 8 & 8 \\
$\mathbf{4}$ & Skor Tertinggi & 37 & 39 \\
$\mathbf{5}$ & Skor Terendah & 21 & 20 \\
$\mathbf{6}$ & Skor Rata-rata & 29.7 & 32.2 \\
$\mathbf{7}$ & Standar Deviasi & 4.3 & 5.5 \\
$\mathbf{8}$ & Varians & 18.9 & 30.7 \\
\hline
\end{tabular}

Dari Tabel 1 terlihat bahwa skor rata-rata yang diperoleh mahasiswa di kelas ICP adalah 29,7 sedangkan pada kelas reguler yaitu 32,2. Gambaran tiap indikator dapat dilihat pada grafik berikut ini.

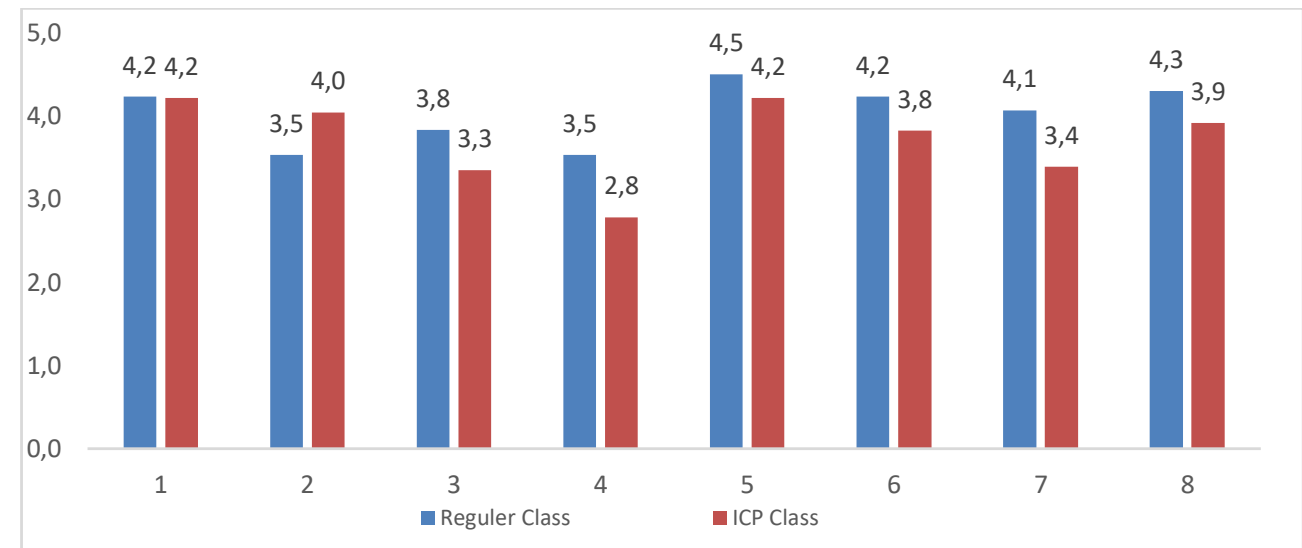

Gambar 1. Grafik skor rata-rata tiap indikator KPS

Keterangan:

1: memformulasikan rumusan masalah

2 : merumuskan hipotesis

3 : menentukan variabel

4 : menuliskan definisi operasional variabel

5 : menenentukan alat dan bahan

6 : merumuskan langkah percobaan

7 : menuliskan hasil penelitian

8 : menuliskan kesimpulan 
Dari grafik dapat dilihat bahwa kedua kelas mempunyai skor terendah pada indikator "menuliskan definisi operasional variabel". Skor tertinggi berada pada indikator "menuliskan alat dan bahan".

\section{b. Data motivasi Belajar}

Angket motivasi belajar diberikan pada kedua kelas yaitu ICP dan reguler dan diperoleh hasil sebagai berikut.

Tabel 2. Data Statistik Skor Motivasi Belajar Calon Guru IPA

\begin{tabular}{ccc}
\hline Statistik & ICP & Reguler \\
\hline Jumlah sampel & 23 & 30 \\
Skor Maksimal & 114 & 125 \\
Skor Minimal & 86 & 87 \\
Rata-rata Skor & 103 & 102 \\
Standar Deviasi & 9.3 & 9.6 \\
Varians & 85.7 & 91.5 \\
\hline
\end{tabular}

Data yang diperoleh mencakup pernyataan positif dan negatif kemudian digabungkan. Nilai maksimal yang bisa diperoleh adalah 28 dikali 5 yaitu 140. Dari Tabel 2 terlihat bahwa untuk kelas ICP rata-rata skor yang dipeoleh calon guru IPA adalah 103 sedangkan pada kelas reguler adalah 102.

\section{c. Data Hasil Belajar}

Data hasil belajar diperoleh dari hasil ujian akhir semester pada mata kuliah IPA sekolah yaitu sebagai berikut.

Tabel 3. Data Statistik Hasil Belajar IPA Sekolah

\begin{tabular}{ccc}
\hline Statistik & ICP & Reguler \\
\hline Jumlah sampel & 23 & 30 \\
Skor Maksimal & 93 & 83 \\
Skor Minimal & 66 & 60 \\
Rata-rata Skor & 83 & 71 \\
Standar Deviasi & 7,4 & 5,6 \\
Varians & 54,2 & 31,0 \\
\hline
\end{tabular}

Dari Tabel 3 menunjukkan bahwa rata-rata skor hasil belajar pada kelas ICP adalah 83 sedangkan pada kelas reguler 71 .

\section{d. Korelasi KPS, Motivasi, dengan Hasil Belajar}

1) Korelasi KPS, motivasi dengan hasil belajar

a) Uji korelasi pada kelas reguler

Hasil uji korelasi pada kelas reguler dapat dilihat pada tabel berikut ini. 
Tabel 4. Hasil Analisis korelasi KPS, Motivasi, dan Hasil belajar kelas Reguler

\begin{tabular}{llrrr}
\hline & & Hasil belajar & kps & motivasi \\
\hline Hasil belajar & Pearson Correlation & 1 & .293 & .247 \\
& Sig. (2-tailed) & & .104 & .174 \\
kps & $\mathrm{N}$ & 32 & 32 & 32 \\
& Pearson Correlation & .293 & 1 & .181 \\
& Sig. (2-tailed) & .104 & .321 \\
motivasi & $\mathrm{N}$ & 32 & 32 & 32 \\
& Pearson Correlation & .247 & .181 & 1 \\
& Sig. (2-tailed) & .174 & .321 & 32 \\
\hline
\end{tabular}

b) Uji korelasi pada kelas ICP

Hasil uji korelasi pada kelas ICP menggunakan SPSS dapat dilihat pada tabel berikut ini.

Tabel 5. Hasil Analisis korelasi KPS, Motivasi, dan Hasil belajar kelas Reguler

\begin{tabular}{llrrr}
\hline & & Hasil belajar & kps & motivasi \\
\hline Hasil belajar & Pearson Correlation & 1 & .415 & -.238 \\
& Sig. (2-tailed) & & .069 & .313 \\
kps & $\mathrm{N}$ & 20 & 20 & 20 \\
& Pearson Correlation & .415 & 1 & -.093 \\
& Sig. (2-tailed) & .069 & .696 \\
motivasi & $\mathrm{N}$ & 20 & 20 & 20 \\
& Pearson Correlation & -.238 & -.093 & 1 \\
& Sig. (2-tailed) & .313 & .696 & 20 \\
\hline
\end{tabular}

Berdasarkan Tabel 4 terlihat bahwa nilai korelasi antara KPS dengan hasil belajar adalah 0 ,293. Nilai ini menunjukan bahwa korelasi antara KPS dengan hasil belajar pada kelas reguler adalah rendah yaitu 0,247 .

Selanjutnya pada Tabel 5 terlihat bahwa nilai korelasi antara KPS dengan hasil belajar pada kelas ICP adalah 0,415. Nilai ini menunjukkan bahwa korelasi keduanya berada pada penafsiran krelasi yang cukup atau sedang.

\section{Pembahasan}

Hasil analisis data untuk melihat korelasi antara KPS dengan hasil belajar pada kelas reguler terlihat bahwa korelasi berada pada kategori rendah. Untuk kelas ICP korelasi kedua variabel tersebut berada pada kategori sedang. KPS untuk kelas reguler kurang berkorelasi dengan hasil belajarnya sedangkan pada kelas ICP memiliki KPS yang cukup berkorelasi dengan hasil belajarnya. Dalam penelitian terkait yaitu penelitian Wila Ingri (2016); P. M Sari, dkk (2008) diperoleh informasi bahwa KPS memiliki korelasi dengan penguasaan konsep dengan kategori cukup.

Penelitian terkait juga dilakukan oleh Miftahul Khairi dkk (2016) yang meneliti hubungan keterampilan proses sains dengan hasil belajar siswa dan menunjukkan bahwa $r=0,87$. Simpulan diperoleh adalah antara keterampilan proses sains dan hasil belajar memiliki hubungan yang kuat melalui pemanfaatan media alami dipandu modul pada sub materi invertebrata di MAS Babun Najah Kota Banda Aceh. 
Secara teori, KPS berkorelasi positif dengan hasil belajar karena untuk menganalisis hasil percobaan dan membuat kesimpulan harus sesuai dengan teori atau materi yang terkait. Hal ini sejalan dengan yang dikemukakan Rustaman (2003) bahwa siswa dapat mempelajari suatu konsep sebagai tujuan pembelajaran melalui pendekatan proses sains.

Hasil penelitian terkait dengan korelasi antara motivasi dengan hasil belajar menunjukkan bahwa korelasi yang rendah. Artinya bahwa motivasi dan hasil belajar saling mempengaruhi tetapi dalam hubungan yang rendah dan terdapat faktor lain yang berpengaruh terhadap hasil belajar selain dari pada motivasi belajar. Penelitian terkait pernah dilakukan oleh Anike Putri, dkk (2015); Febrianto (2013) yang menemukan bahwa terdapat hubungan yang signifikan antara motivasi belajar dengan hasil belajar peserta didik. Hasil yang diperoleh tersebut juga memperlihatkan adanya faktor luar yang berpengaruh terhadap hasil belajar selain motivasi belajar. Hal ini dikemukakan oleh Anitah (2008) bahwa keberhasilan belajar sangat dipengaruhi oleh beberapa faktor yaitu faktor dalam diri peserta didik sendiri (intern) dan faktor luar diri siswa (ekstern).

\section{KESIMPULAN}

Berdasarkan hasil penelitian maka dapat disimpulkan sebagai berikut:

1. Terdapat hubungan antara keterampilan proses dengan hasil belajar calon guru IPA pada kelas reguler dengan kategori rendah dan pada kelas ICP dengan kategori sedang atau cukup.

2. Terdapat hubungan antara motivasi dengan hasil belajar calon guru IPA pada kelas Reguler maupun kelas ICP yang berada kategori rendah.

\section{DAFTAR PUSTAKA}

Anike Putri, Emilia Dewiwati Pelipa. 2015. Hubungan Motivasi Belajar Dengan Hasil Belajar Siswa Pada Mata Pelajaran IPA Di Sekolah Dasar. Jurnal Pendidikan Dasar PerKhasa Volume 1, Nomor 1, Oktober 2015.

Anitah, Sri. (2008). Strategi Pembelajaran di SD. Jakarta: Universitas Terbuka.

Aydogdu, Bullent. 2015. The investigation of Science Process Skill of Science Teachers in terms of some variables. Academic Journal. Vol 10 (5), pp. 582-594

Bass, JE, Contant, TL, \& Carin, AA. 2005. Methods for Teaching Science as Inquiry. Allyn \& Bacon. Pearson. USA.

Dimyati and Mudjiono. 2002. Belajar dan Pembelajaran. Jakarta: Rineka Cipta

Febrianto, Beni. (2013). Hubungan Motivasi Belajar Dengan Hasil Belajar Bahan Bangunan Siswa Kelas X Bangunan di SMK N 1 Tanjung Raya. CIVED ISSN 2302- 3341, Vol. I, Nomor 2, Juni 2013.

Miftahul Khiri, m. Ali. S, Abdullah. 2016. Hubungan Keterampilan Proses Sains Dengan Hasil Belajar Siswa melalui Pemanfaatan Media Alami Dipandu Modul Pada Submateri Invertebrata Di Mas Babun Najah Kota Banda Aceh. Jurnal EduBio Tropika, Volume 4, Nomor 2, Oktober 2016, hlm. 1-52

Mutlu, M \& Temiz BK. 2013. Science Process Skill of students having field dependent and field independent cognitive style. Educ. Res. Rev. 8(11); 766-776.

P M Sari, F Sudargo, and D Priyandoko Correlation among science process skill, concept comprehension, and scientific attitude on regulation system materials . Journal of Physics: Conf. Series 948 (2018) 012008.

Rustaman, Nuryani Y, Soendjojo D, Suroso A Y, Yusnani A, Ruchji S, Diana R and Mimin N K.2003 Strategi Belajar Mengajar Biologi (Bandung: Jurusan Pendidikan Biologi FPMIPA UPI) 
Tobin KG, \& Capie W., 1962. Relationship between formal reasoning ability, locus of control, academic engagement and integrated process skill achievement. J. Res. Sci. Tech. 19; 113-121

Tuti Respati. 2013. Hubungan Pemahaman Keterampilan Proses Sains dengan Hasil Belajar Biologi Siswa Kelas XI IPA SMAN 1 Padang Tahun Pelajaran 2012/2013. Skripsi. Universitas Negeri Padang

Willa Ingri Angraini. 2016. Kontribusi Kemampuan Keterampilan Proses Sains Terhadap Penguasaan Konsep Siswa Di Kelas V Sekolah Dasar. Program Studi Pendidikan Fisika FKIP Untan Pontianak.

\section{Sitti Rahma Yunus}

Dosen Program Studi Pendidikan IPA FMIPA UNM, aktif melakukan penelitian pada bidang Pendidikan IPA, dapat dihubungi melalui email: sitti.rahma.yunus@unm.ac.id

\section{Muhammad Aqil Rusli}

Dosen Program Studi Pendidikan IPA FMIPA UNM, aktif melakukan penelitian pada bidang Pendidikan IPA, dapat dihubungi melalui email: m.aqilrusli@gmail.com

\section{Nurhayani H. Muhiddin}

Dosen Program Studi Pendidikan IPA FMIPA UNM, aktif melakukan penelitian pada bidang Pendidikan IPA, dapat dihubungi melalui email: nurhayanio8@gmail.com

\section{Hasanuddin}

Dosen Program Studi Pendidikan IPA FMIPA UNM, aktif melakukan penelitian pada bidang Pendidikan IPA, dapat dihubungi melalui email: ulfaizahnoer18@gmail.com 